\title{
Problem-Based Learning-Buginese Cultural Knowledge Model—Case Study: Teaching Mathematics at Junior High School
}

\author{
Cheriani ${ }^{1}$, Alimuddin Mahmud ${ }^{1}$, Suradi Tahmir ${ }^{1}$, Darman Manda ${ }^{1} \&$ Gufran Darma Dirawan ${ }^{1}$ \\ ${ }^{1}$ Makassar State University, Indonesia \\ Correspondence: Cheriani, Makassar State University, Indonesia. E-mail: cheriani@ymail.com
}

Received: August 25, 2014

Accepted: November 20, 2014 Online Published: March 29, 2015

doi:10.5539/ies.v8n4p104

URL: http://dx.doi.org/10.5539/ies.v8n4p104

\begin{abstract}
This study aims to determine the differences in learning output by using Problem Based Model combines with the "Buginese" Local Cultural Knowledge. (PBL-Culture) It is also explores the students activities in learning mathematics subject by using PBL-Culture Models. This research is using Mixed Methods approach that combined quantitative and qualitative methods and Sequential Explanatory Design (SED) Models that implemented at junior high school, at Bone Regency in South Sulawesi Province. The results of this study stated that Firstly, Junior high student learning outputs has increased significantly after being taught by using the PBL-Culture Models Secondly, the learning activities output showed that students have high attitude in the siri', pesse', sipatuo-sipatokkong categories after teach by using PBL-Culture, meanwhile, medium attitude in the siri', sipatuo-sipatokkong categories for non experimental classes. However at pesse' categories, the models shows difficulties in learning and solving problems Moreover the result also showed that students has a low ability at siri' categories depends on the situation given by the teacher and the situation surrounding environment.
\end{abstract}

Keywords: problem based models, mathematics, cultural based models

\section{Background}

Indonesian is currently facing two major challenges in education system, namely government programs in education decentralization and globalization that is going to happen in 2020. Both of these challenges have to be passed and prepared by all education stakeholders in Indonesia. The key to success in the face this challenges is to improve the quality of human resources, Indonesian through education (Muslich, 2010).

On the other hand, the fact shows different conditions, the local communities in Indonesia. The local community facing and experiencing moral degradation that caused by lack of local wisdom has not been teach from the one generation to the next generation, the phenomenon can be observed from a lot of social conflicts in the community livelihoods especially at the school/ As can be seen also a lot of demonstration that tend to be anarchists, and the widespread violence in many area, and there are high number of students has been involved with violence, drugs and fights among students (Talib et al., 2009). Negative behavior is also seen from students of Junior high school in Indonesia in learning activities for examples: there are big number students who believe that cheating on tests is not problems, the use of language and words that are not appropriate in between the learning process and distrust in working on the problems that has been given by the teachers.

Based on research at Harvard University United States, it turns out that the success of students is not determined solely by their knowledge and technical abilities (hard skills), but rather by the ability to manage themselves and others (soft skills). This study also reveals, success is determined only approximately 20 percent by the hard skills and the remaining 80 percent by soft skills. Even the most successful people in the world could succeed because of the ability to support more soft skills than hard skills. This suggests that the quality of education students are very important character to be improved (Sudrajat, 2010).

Furthermore, National Education Goals stated that students should be able to improve their knowledge, attitudes, and ability on one hand and they also should have comparative advantages and competitive advantages in facing the era of globalization. Teacher as an educators in this regard should be able to apply a model that can integrate high curiosity character (exploratory), creative, critical, dare to try, sure can do (self-efficacy), honest, responsible for duties, cooperation, discipline, hard work, able to organize themselves, cooperate with others and reflection to achieve the goal (self-regulatory), as mandated by the National Education System (Education Law) 
no. 20 of 2003 Article 3 (Hasan, 2010).

By focusing at mathematics subjects, the mental activity for students in this subject is needed to be improved in conjunction with their cognitive activity. Human cognitive activities can only take place in the social and cultural environment when it has ability to adopt their cultural behavior. Experts assert that constructivist mathematics culture bound and filled with the values of the inventor/user of mathematics in the context of their culture. According to Vygotsky indicates that development cannot be separated from its social and cultural context, so the only way to explore the mental processes is through understanding Vygotsky's concept of mediation that made a Breakthrough in our understanding of learners 'development' (Eun, 2008, p. 136; Shabani, Khatib, \& Ebadi, 2010, p. 238; Talib et al., 2010, p. 93).

Cognitive development and the value of human has an affective interaction if the learner can only adapt their cognitive ability through the social-cultural context of each individual especially in the Buginess community particularly in adopting the Buginess culture in the learning process. Each learning activity required an interaction of teaching, better interaction in-between students, student Interaction with the teacher and student interactions with other learning devices (Suradi, 2005; Yackel, Cobb, \& Wood, 1991; Atweh, Bleicher, \& Cooper, 1998; Jones \& Thornton, 1993). Therefore this research will determine differences in learning output by using Problem Based Model combines with Cultural Knowledge.(PBL-Culture) It is also explores the students activities in process of learning mathematics subject by using PBL-Culture Models, and how the students' response to this model.

\section{Research Methods}

This research is a Mix Methods that combine quantitative and qualitative research and combine with Sequential Explanatory Design Model. This research was conducted at Junior high school, at Bone Regency South Sulawesi Province. The population of this research is all the eighth grade students of junior high school 3 in year 2012/2013, amounting to 224 people spread over 8 parallel classes. Sampling technique in this study is using purposive sampling methods followed by the determination of research subjects by using the deepest interview. This determination of the result is based on learning achievement test results after treatment and tailored to the mathematical subject of class VII semester of the school year 2012/2013. The next set of categories of high ability, medium and low based on the categorization according Suradi (2005). Research instruments, in the form of (i) the learning achievement test, (ii) the student activity sheets, (iii) student questionnaire responses (iv) the guidelines for the interview. Quantitative data were analyzed by using descriptive statistics and inferential statistical analysis and calculation of quantitative data used application program SPSS version 20.0 statistical analysis, while qualitative data used for the analysis of models of Miles and Huberman. Observation of student activities using instruments LOAS, analyzed and described with reference to the criteria for the achievement of the ideal time student activity (modified from Widyaningsih , 2010).

\subsection{Hypothesis Statistics}

The hypothesis in this study was "There are differences in student output achievement before and after being taught with a problem-based learning model with the Buginese culture".

\section{Results}

\subsection{Linkage between Buginees Cultural Aspects in Problem Based Learning Models}

In phase-1, Buginese Cultural aspects are involved siri'andsipatuo-sipatokkong categories. In this phase the student's knowledge relating to the material to be covered materials that developed by improving students attitudes in the class rooms by introducing cultural aspect, so that students are not empty. This is in line with the constructivist theory.

In phase-2, Buginese Cultural aspects involved is siri', sipatuo-sipatokkong and pesse' categories. Students construct knowledge in groups led by a chairman of class rooms. Siri' aspect in this phase is the responsibility of the individual, sipatuo-sipatokkong aspect lies in cooperation aspects, and pesse' aspect lies in providing assistance to members of the group requires. Associated with goal-construct the knowledge, it is clearly supported by constructivist theory. Construction is being carried out in groups is supported by Vygotsky's theory. In addition, a portion of the construction of knowledge is achieved through a process of discovery that is consistent with the theory of Bruner.

In phase-3, Buginese Cultural aspects are involved such as the phase-3 is siri', sipatuo-sipatokkong and Pesse. In this phase, the specific activities of the group are the percentage of teacher assistance as necessary in line with Vygotsky's theory of ZPD. 
In phase-4, Buginese Cultural aspects involved that siri', sipatuo-sipatokkong and Pesse. Here the teacher's role is more dominant, however, knowledge is formed by students with the guidance of a teacher. This is in line with the constructivist theory.

Phase-5; Cultural aspects are involved, namely Buginese siri', sipatuo-sipatokkong and Pesse is to analyze and evaluate the problem-solving process. This is in line with the constructivist theory.

\subsection{Description of Student Achievement}

Descriptive analysis related to student learning achievement obtained through learning achievement tests show that the average value of learning achievement of students prior to the implementation of the PBL-Culture Models is 33.57 with a standard deviation of 11.21. Based on the categorization of the Ministry of National Education (2003) of which there are 28 students, 18 students (64.28\%) were in the category of very less and 10 other students $(35.72 \%)$ were in the poor category while no students who are at category of medium, high and very high. While the average value of learning achievement of students after implementation of the PBL-Culture Model is 80.71 with a standard deviation of 9.88. Based on the categorization of the Ministry of National Education (2003), of which there are 28 students, 7 students (25\%) were in the moderate category, 19 students $(67.86 \%)$ were in the high category and 2 other students $(7.14 \%)$ at the high category and no longer in the category of students who are less and less so.

\subsection{Description of Student Activity in PBL Model of Buginese Culture}

Analysis of the results of observations is seen from student activity during the four meetings. Table 1 shows the results of the analysis of observations of student activity PBL Buginese culture models in two sample groups:

Table 1. The Average percentage of time the student activity PBL-Buginese culture group

\begin{tabular}{|c|c|c|c|c|c|c|}
\hline \multirow{2}{*}{ Categories of student activity } & \multicolumn{4}{|c|}{ Meeting } & \multirow{2}{*}{ Average } & \multirow{2}{*}{ Criteria } \\
\hline & 1 & 2 & 3 & 4 & & \\
\hline K1 & 19.00 & 20.00 & 20.00 & 20.00 & 19.75 & $13.75-23.75$ \\
\hline $\mathrm{K} 2$ & 32.00 & 29.00 & 31.00 & 30.00 & 30.50 & $26.25-36.25$ \\
\hline K3 & 18.00 & 22.00 & 19.00 & 22.00 & 20.25 & $13.75-23.75$ \\
\hline K4 & 3.00 & 3.00 & 5.00 & 3.00 & 3.50 & $1.25-11.25$ \\
\hline K5 & 13.00 & 15.00 & 13.00 & 14.00 & 13.75 & $13.75-23.75$ \\
\hline K6 & 10.00 & 9.00 & 10.00 & 10.00 & 9.75 & $1.25-11.25$ \\
\hline K7 & 5.00 & 2.00 & 2.00 & 1.00 & 2.50 & $0-5$ \\
\hline Total & 100 & 100 & 100 & 100 & 100 & \\
\hline
\end{tabular}

Table 2. Average percentage of time the student activity PBL-Culture Models group 4

\begin{tabular}{|c|c|c|c|c|c|c|}
\hline \multirow{2}{*}{ Categories of student activity } & \multicolumn{4}{|c|}{ Meeting } & \multirow{2}{*}{ Average } & \multirow{2}{*}{ Criteria } \\
\hline & 1 & 2 & 3 & 4 & & \\
\hline K1 & 20.00 & 20.00 & 20.00 & 20.00 & 20.00 & $13.75-23.75$ \\
\hline $\mathrm{K} 2$ & 29.00 & 27.00 & 30.00 & 31.00 & 29.25 & $26.25-36.25$ \\
\hline $\mathrm{K} 3$ & 21.00 & 23.00 & 21.00 & 22.00 & 21.75 & $13.75-23.75$ \\
\hline $\mathrm{K} 4$ & 3.00 & 3.00 & 5.00 & 3.00 & 3.50 & $1.25-11.25$ \\
\hline K5 & 14.00 & 14.00 & 14.00 & 14.00 & 14.00 & $13.75-23.75$ \\
\hline K6 & 9.00 & 10.00 & 10.00 & 10.00 & 9.75 & $1.25-11.25$ \\
\hline K7 & 4.00 & 3.00 & 0.00 & 0.00 & 1.75 & $0-5$ \\
\hline Total & 100 & 100 & 100 & 100 & 100 & \\
\hline
\end{tabular}

Based on the analysis of data in the table above, the category of student activity (K1), (K2), (K3), (K4) and (K5) which is a core activity in PBL-Culture Models meets the tolerance interval of time achieving the ideal(PWI). 
Thus, the ideal activity for students concluded PBL-Culture Models is meet the criteria that has been assign by the Minister of Education.

\subsection{Description of Student Responses PBL-Culture Models}

Based on analysis of student response data (attached) obtained in response to the students' learning component PBL-Culture Models is $98.22 \%$ said 'happy', and $98.81 \%$ said 'new'. Student responses on the language used in the student book, worksheets, and tests of learning achievement is $96.43 \%$ said 'clear', $100 \%$ of students consider their learning progress after the implementation of the PBL-Culture Models, $100 \%$ interest in the application of the PBL-Culture Models, 100\% agree with the application of the PBL-Culture Models and 100\% say interesting for the application of the PBL-Culture Models.

\subsection{Testing Hypothesis}

Based on the results of t-test with SPSS $20.0 \mathrm{p}$ values obtained in table (Look At Sig. (2-tailed)) is 0.000, meaning the value of $\mathrm{p} \geq 0.05$. Thus the hypothesis $\mathrm{H} 0$ is rejected or accepted, which means there are $\mathrm{H} 1$ student achievement differences before and after being taught with PBL-Culture Models.

Table 3. The results of t-test

\begin{tabular}{|c|c|c|c|c|c|c|c|c|}
\hline \multicolumn{9}{|l|}{ Paired Samples Test } \\
\hline & \multicolumn{5}{|c|}{ Paired Differences } & \multirow{3}{*}{$\mathrm{T}$} & \multirow{3}{*}{ df } & \multirow{3}{*}{$\begin{array}{c}\text { Sig. } \\
\text { (2-tailed }\end{array}$} \\
\hline & \multirow[t]{2}{*}{ Mean } & \multirow[t]{2}{*}{ Std. Deviation } & \multirow{2}{*}{$\begin{array}{l}\text { Std. Error } \\
\text { Mean }\end{array}$} & \multicolumn{2}{|c|}{$\begin{array}{l}95 \% \text { Confidence Interval of } \\
\text { the Difference }\end{array}$} & & & \\
\hline & & & & Lower & Upper & & & \\
\hline${ }_{1}^{\text {Pair }}$ PRETEST-POSTTEST & $-47,14286$ & 6,86221 & 1,29684 & $-49,80374$ & $-44,48197$ & $-36,352$ & 27 &, 000 \\
\hline
\end{tabular}

\section{Discussion}

In general, student achievement has increased significantly based on the results of the data analysis. More specifically the authors look at the differences of learning achievement based on ability level. Students with high ability to subject of ANA test scores before the application is 55, after the application of the PBL-Culture Models the test score increase significantly t to 95 , with an increase of 40 points. Similarly, the subject HAR of 50 to 90 means also increased 40 points. Student 's ability to subject the WSH was also increased from 50 to 85 has increased 35 points, while the subject of the RIS has increased 45 points from 40 to 85 . While low ability students to the subject of the UVD has increased 45 points, from 20 to 65 , subject FIT has increased 45 points from 25 to 70 .

As can be seen in this improvement of three abilities above was moderate ability and low ability increased significantly to match and even exceed the high scores. This suggests that the better student achievement, high ability students are getting smarter, student ability and low ability was also improved academic achievement "approaching" the ability of students who are smarter. This suggests that the involvement of the cultural aspects of Buginese either siri' or motivation for achievement student achievement, pesse and sipatuo-sipatokkong in problem-based learning model affect student achievement, especially the learning of mathematics.

\subsection{Exploration Activity in PBL-Culture Models}

Based on observations and interviews about student activities above can be presented in tabular form as follows:

Table 4. Student Activities based on the level of ability

\begin{tabular}{llllll}
\hline \multirow{5}{*}{ No Aspect } & \multicolumn{3}{l}{ Level } & & \\
\cline { 3 - 5 } & & Low & Medium & High & Conclusion \\
& & Ability & Ability & Ability & \\
& & (LA) & (MA) & (HA) & \\
\hline 1 & Siri & & & & \\
\hline
\end{tabular}


siri'masiri'(achievem Good

ent motivation)

Matinulunarululaku-l $a k u$ (A job well done)

c.

Mammenasarideceng atuwongnge

(The desire for a good value)

\section{d. Lempuk (honest )}

Good

e. Mappesona ri dewata seuae (surrender to God Almighty )

f. Getteng (stead fast belief that true/commitment )

\section{Pesse}

a.

Sibaliparirilalengattu ntukengpaddissengen gsibawarilalengjamaj amang (Helping friends who have difficulty in learning and task)

b.

Napainrengisibawan naruparupannaripake magguru (Friends lend equipment in learning)
Excellent

Excellent

A seriousness level students in learning is dependent on the teacher's situation, environment. While the students' level of MA, HA does have an innate motivation.

Excellent Excellent Excellent

Excellent Excellent

Excellent

Giving a task/problem set by the teacher for all levels demonstrate a commitment and responsibility to complete the task as well as possible individually or in groups.

The desire of students to get good scores of seriousness and activity showed great motivation to learn, pay attention to the teacher's explanation, completing the task in accordance with the specified time.

Excellent

Excellent

Activity level students demonstrated HA and MA shows honesty, trying to answer exam questions in accordance with the capabilities, but at the level of LA sometimes take shortcuts (cheating on exams), has the desire to obtain a good value destroying roads siri'(honest).

Excellent Excellent Excellent

Allshowed activity levels will be into pray every learning and test execution with expectations given the smoothness and easiness at the time of the exam.

Excellent Excellent Excellent

Shown great commitment to learning at all levels of visible readiness to learn, trying to resolve the problem on an individual work sheet although the level at the beginning of the meeting has not been maximized.

Good Excellent Excellent

All levels pesse' basically had the attitude 'to help his friend who had difficulty in learning, students HA be happy to help a friend who both learning difficulties and tasks to the level of the MA and LA, MA also helps his students when it has more capabilities. But at the level of MA only help her for the things that they can.

Excellent Excellent Excellent

All levels of students have a sense of Pesse' when looking at the others require learning tools (ruler, tipe-x, pens, and other learning tools). 
3. Sipatuo- sipatokkong

a.

Napariatiwipappanes

sanaguruesibawasilo

nna) (Pay attention to

the teacher's

explanation or

friends)

b.

Naengkalingaipappa

ngajanagurue (Listen

to and follow the

advice of teachers)

c.

Makkutanairiguruena

sabagaumakkeade

(Ask or answer questions in a polite way)

d.

Sibalipangararipalla wangennatomasseddi

$e$ (The existence of communication

between groups)

e. Punnaiwisipa'

asseddingeng (It has

the feeling of

togetherness)
Less

Excellent

Excellent

Excellent

Excellent

Excellent

Excellent Excellent

Excellent

All

students

establish

communication between members of the group, with good discussion and mutual respect opinions. It appears from the student activities undertaken and supported by the results of the interview.

Excellent Excellent

Excellent

Since the start until the end of the study, all students showed togetherness, the task given by the teacher (in the form of LKS) solved together in a group. Sipatuo sipatokkong all levels are excellent. This is also supported by the results of the interview.

\subsection{Students' Response to the Application of the PBL-Culture Models}

In general, good argues, students feel happy and exercising new learning component, students found the language used in the student book, the content of the LKS, has clear meaning and improving learning achievement test, students feel there is progress and interest after learning mathematics in context of Buginese culture and improving this model in the subject of mathematics.

\section{Conclusion}

Junior high student achievement has increased significantly before and after being taught by using the PBL-Culture Models. The results of this research shows that students can achieve good attitudes and high ability in their performance in the learning process and output by using PBL-Culture Models that consist of several categories such as: siri', pesse', sipatuo-sipatokkong is high in experiment class that using PBL-Culture Model, medium abilities also have the attitude siri', sipatuo-sipatokkong but pesse' help her difficulties in learning and solving problems in LKS extent their can, also has a low ability attitude siri' depends on the situation given by the teacher and the situation surrounding environment. Students' response to the application of the PBL-Buginese culture model is generally well argued. Students feel happy and new learning component, students found the language used in the book the student, the content of the LKS, and clear learning achievement test, students feel 
there is progress and interest after learning mathematics PBL-Buginese culture model and agree with PBL-Buginese culture if the model is applied in learning mathematics.

\section{References}

Atweh, B., Bleicher, R. E., \& Cooper, T. J. (1998). The Construction of the Social Context of Mathematics Classrooms: A Sosiolinguitics Analysis. Journal of Research in Mathematics Education, 29(1), 63-82. http://dx.doi.org/10.2307/749718

Eun, B. (2008). Making Connections: Grounding Professional Development in the Developmental Theories of Vygotsky. Journal of the Teacher Educator, 43(2), 134-155. http://dx.doi.org/10.1080/08878730701838934

Hasan, S. H. (2010). Development Culture and National Character Education. Presented at the Training Reinforcement Learning Methodology Based Cultural Values for Shaping Competitiveness and National Character. Jakarta: Ministry of National Education Research and Development Center Curriculum.

Jones, G, A., \& Thornton, C. A. (1993). Vygotsky Revisited: Nurturing Young Children's Understanding of Number. Focus on Learning Problems in Mathematics, 15(2\&3), 18-28. Center for Teaching/Learning of Mathematics.

Ministry of Education. (2004). Curriculum 2004. Competency Standards Lesson Junior High School Mathematics and Islamic. Jakarta: Ministry of Education.

Muslich, M. (2010). Challenges Character Education Answering Multidimensional Crisis. London: Earth Literacy.

Shabani, K., Khatib, M., \& Ebadi, S. (2010). Vygotsky's Zone of Proximal Development: Instructional Implications and Teachers' Professional Development. Journal of English Language Teaching, 3(4), 238. http://dx.doi.org/10.5539/elt.v3n4p237

Sudrajat, A. (2010). Concepts Character Education in Schools. Retrieved October 1, 2011, from http://akhmadsudrajat.wordpress.com/2010/09/15/konsep-pendidikan-karaHAer/

Suradi. (2005). The Interactions Among Junior High Shool Students in Cooperative Learning of Mathematics. (Dissertation, not published). Surabaya: Program of Postgraduate, State University of Surabaya.

Talib, S. B. (2010). Empirical Analysis Based Educational Psychology Applicative. New York: Golden Prenada Media Group.

Widaningsih, D. (2010). Planning Learning mathematics. London: Rizqi Press.

Yackel, E., Cobb, P., \& Wood, T. (1991). Small Group Interaction as a Source of Learning Opportunities in Second-Grade Mathematics. Journal of Research in Mathematics Education, 22(5), 390-408. http://dx.doi.org/10.2307/749187

\section{Copyrights}

Copyright for this article is retained by the author(s), with first publication rights granted to the journal.

This is an open-access article distributed under the terms and conditions of the Creative Commons Attribution license (http://creativecommons.org/licenses/by/3.0/). 